\title{
INTENSITAS SERANGAN HAMA KUMBANG MONCONG PADA AGROFORESTRI AKOR (Acacia auriculiformis)
}

\author{
(Intensity Level of Weevil Pest on Akor (Acacia auriculiformis) Agroforestry)
}

\author{
Endah Suhaendah dan M. Siarudin \\ Balai Penelitian dan Pengembangan Teknologi Agroforestry \\ Jl. Raya Ciamis-Banjar Km. 4 Ciamis 46201 Telp. (0265) 771352, Fax. (0265) 775866 \\ Email: endah_ah@yahoo.com; msiarudin@yahoo.com
}

Diterima 25 Januari 2019, direvisi 7 Mei 2019, disetujui 19 Juni 2019

\begin{abstract}
The combination of tree species and agricultural crops in agroforestry systems can affect the type and intensity of attacks by pests and diseases. This study aims to determine incidence level and intensity level of weevil pests in two patterns of akor agroforestry. Observations were made on two akor-based agroforestry patterns: akor (Acacia $\underline{\text { auriculiformis }})+$ black pigeon pea $(\underline{\text { Cajanu scajan }})+$ rice $(\underline{\text { Oryza sativa }})$ (Pattern 1); and akor ( $\underline{\text { A.auriculiformis })}+$ black pigeon pea (‥cajan) + green bean (Vigna radiata) (Pattern 2). The number of plant samples observed were 30 trees randomly selected in each pattern. The parameters observed were incidence level and intensity level of weevil pest attacks. The observations showed that incidence level of Hypomeces squamosus were 100\% in pattern 1 and $96.7 \%$ in pattern 2. Intensity level of the $H$. squamosus weevil in pattern 1 and pattern were $81.06 \%$ and $6.21 \%$ respectively. The higher intensity of H.squamosus attacks in pattern 1 was due to the presence of rice plants as another host of $\underline{H}$. squamosus. Control measures that can be applied include rotation of host plant other than the host plant of $H$. Squomasus. If a pest population explosion occurs then bio-perticides or chemical pesticides made from active ingredients of acephate, carbaryl or methamidophos can be applied to restore the pest population to the principle of balance.
\end{abstract}

Keywords: agroforestry patterns, intensity of attacks, pests and diseases, type of attack

\begin{abstract}
ABSTRAK
Kombinasi jenis pohon dan tanaman pertanian pada sistem agroforestri dapat berpengaruh pada jenis dan intensitas serangan hama dan penyakit. Penelitian ini bertujuan untuk mengetahui persentase serangan dan intensitas serangan hama kumbang moncong pada dua pola agroforestri akor. Pengamatan dilakukan pada dua pola agroforestri berbasis akor, yaitu: akor (Acacia auriculiformis) + kacang gude hitam (Cajanus cajan) +padi (Oryza sativa) (Pola 1) dan pola akor $($ A. auriculiformis) + kacang gude hitam (C. cajan) + kacang hijau (Vigna radiata) (Pola 2). Jumlah sampel tanaman yang diamati adalah 30 pohon yang dipilih secara acak pada masing-masing pola. Parameter yang diamati adalah persentase serangan dan intensitas serangan hama kumbang moncong. Hasil pengamatan menunjukkan bahwa persentase serangan Hypomeces squamosus mencapai $100 \%$ pada pola 1 dan $96,7 \%$ pada pola 2 . Intensitas serangan kumbang moncong $H$. squamosus pada pola 1 dan pola masing-masing sebesar 81,06\% dan 6,21\%. Lebih tingginya intensitas serangan $H$. squamosus pada pola 1 disebabkan adanya tanaman padi sebagai inang lain $H$. squamosus. Upaya pengendalian yang dapat dilakukan diantaranya pengelolaan ekosistem melalui rotasi tanaman padi dengan jenis lain yang bukan inang $H$. squamosus. Jika terjadi ledakan populasi hama maka digunakan pestisida nabati atau kimiawi secara selektif untuk mengembalikan populasi hama pada asas keseimbangannya dengan aplikasi ekstrak cabai rawit atau insektisida berbahan aktif acephate, carbaryl atau methamidophos.
\end{abstract}

Kata kunci: Hama dan penyakit, intensitas serangan, jenis serangan, pola agroforestri 


\section{PENDAHULUAN}

Akor (A. auriculiformis) adalah salah satu jenis cepat tumbuh yang banyak dibudidayakan di hutan tanaman baik lahan masyarakat maupun kawasan hutan. Akor termasuk jenis legum yang dapat mengikat nitrogen, mencegah erosi tanah, memperbaiki kesuburan tanah, serta menjadi penyedia pakan ternak (Azad \& Sumon, 2016; Lalitha, 2015). Selain itu jenis ini juga dikenal dapat beradaptasi pada lahan kering dan marjinal (R. L. Hendrati, Rachmawati, \& Pamuji, 2016).

A.auriculiformis merupakan salah satu pohon sumber energi. Kayunya memiliki potensi kalor dan arang yang sangat menjanjikan. Oleh karena itu, biomass dari kayu cepat tumbuh diprediksi akan digunakan secara ekstensif terutama jika hal itu lebih mudah dan lebih murah didapatkan daripada alternatif sumber bahan bakar lain (R. Hendrati, Nurrohmah, Susilawati, \& Budi, 2014).

Penanaman akor dalam sistem agroforestri merupakan salah satu upaya untuk mengoptimalkan lahan dengan memanfaatkan lahan kosong dibawah tegakan pohon dengan budidaya tanaman pertanian. Tanaman pohon dan tanaman pertanian dalam sistem agroforestri dapat saling berinteraksi baik positif maupun negatif (Hairiah, van Noordwijk, \& Suprayogo, 2008). Adanya jenis tanaman yang beragam pada sistem agroforestri dapat berpotensi mengurangi resiko serangan hama dan penyakit (Schroth, Krauss, Gasparotto, Aguilar, \& Vohland, 2000). Namun demikian, keanekaragaman jenis tanaman tidak serta merta menurunkan serangan hama dan penykait mengingat jenis organisasi pengganggu tanaman tertentu dapat menyerang beberapa jenis tanaman yang berbeda (Pumarino et al., 2015; Ratnadass, Fernandes, Avelino, \& Habid, 2012). Serangan hama dan penyakit karena adanya kesamaan inang antara tanaman pohon dan tanaman pertanian dapat muncul sebagai salah satu bentuk interaksi tidak langsung (Hairiah et al., 2008). Dengan demikian perbedaan komposisi jenis penyusun sistem agroforestri dapat menyebabkan perbedaan jenis dan intensitas serangan hama dan penyakitnya (Pumarino et al., 2015).

Beberapa penelitian mengenai serangan hama dan penyakit pada sistem agroforestri telah dilakukan, di antaranya Maharani, Susilo, Swibawa, and Prasetyo (2013); Utami and Ismanto (2017); Sudiono, Sutjahyo, Wijayanto, Hidayat, and Kurniawan (2017). Namun demikian penelitian mengenai jenis hama dan penyakit pada sistem agroforestri yang mengkaitkan antar pola tanam (komposisi jenis tanaman) masih sangat terbatas, khususnya dengan jenis pohon pokok akor.

Penelitian ini bertujuan untuk mengetahui persentase serangan dan intensitas serangan kumbang moncong Hypomeces squamosus pada dua pola agroforestri dengan pohon pokok akor. Informasi hasil penelitian ini diharapkan dapat menjadi pertimbangan dalam mempertimbangkan pemilihan pola agroforestri akor dan upaya untuk pengendalian hama dan penyakitnya.

\section{BAHAN DAN METODE}

\section{A. Waktu dan Lokasi Penelitian}

Penelitian dilakukan pada demplot agroforestri akor yang berada di wilayah Resort Pengelolaan Hutan (RPH) Kanarluk, Kesatuan Pengelolaan Hutan Produksi (KPHP) Puncak Ngengas-Batulanteh, Kabupaten Sumbawa, Nusa Tenggara Barat. Lokasi ini berada pada ketinggian $40-65 \mathrm{~m}$ dpl, pada koordinat $08.47681^{\circ} \mathrm{S}$ dan $117.32990^{\circ} \mathrm{E}$. Tanaman akor yang diamati berumur 1 tahun. Pengamatan dilakukan pada bulan Juni 2016.

\section{B. Metode Pengumpulan dan Analisis Data}

Pengamatan dilakukan pada dua pola agroforestri berbasis akor, yaitu: akor (A. 
auriculiformis) + kacang gude hitam (Cajanus cajan) + padi (Oryza sativa) (Pola 1) dan pola akor (A. auriculiformis) + kacang gude hitam (Cajanus cajan) + kacang hijau (Vigna radiata) (Pola 2). Tanaman akor di tanam dengan jarak tanam $1 \mathrm{~m}$ x $4 \mathrm{~m}$ pada plot berukuran $12 \mathrm{~m} \times 28 \mathrm{~m}$. Pada pola 1, tanaman gude ditanam dengan jarak $4 \mathrm{~m}$ x $4 \mathrm{~m}$ pada lorong antara tanaman akor, sedangkan padi ditanam dengan jarak tanam $30 \mathrm{~cm}$ x $30 \mathrm{~cm}$ diantara tanaman akor dan gude. Pada pola 2, tanaman kacang hijau ditanam dengan jarak tanam $40 \mathrm{~cm} \times 20 \mathrm{~cm}$ pada lorong antara tanaman akor.

Jumlah sampel tanaman akor yang diamati adalah 30 pohon yang dipilih secara acak pada masing-masing pola dengan intensitas sampling 10\%. Parameter yang diamati adalah persentase serangan dan intensitas serangan hama kumbang moncong. Persentase serangan diperoleh berdasarkan perbandingan antara jumlah pohon yang terserang terhadap jumlah total pohon dalam satu plot pengamatan (Suhaendah, 2013). Nilai intensitas serangan diperoleh dengan menggunakan rumus sebagai berikut:

$$
I S(\%)=\frac{\sum\left(n_{i} \times v_{i}\right)}{Z \times N} \times 100 \%
$$

Dimana:

$$
\begin{aligned}
I S(\%)= & \text { Intensitas serangan } \\
n_{i}= & \text { Jumlah tanaman dengan nilai skala } \\
& \text { ke- } i \\
v_{i} \quad & \text { Nilai skala dari setiap kategori } \\
& \text { serangan ke- } i \text { (Tabel 1) } \\
Z \quad= & \text { Nilai skala dari kategori serangan } \\
& \text { yang tertinggi } \\
N \quad= & \text { Jumlah tanaman yang diamati. }
\end{aligned}
$$

\begin{tabular}{|c|c|c|}
\hline $\begin{array}{l}\text { Tingkat kerusakan } \\
\text { (Degree of damage) }\end{array}$ & $\begin{array}{l}\text { Kriteria kerusakan pada tanaman } \\
\text { (Criteria for damage to plant) }\end{array}$ & $\begin{array}{l}\text { Nilai skala kerusakan } \\
\text { (Damage scale value) }\end{array}$ \\
\hline Sehat & $\begin{array}{ll} & \text { Tidak ada serangan } \\
\text { - } & \text { Daun rusak kurang dari } 5 \%\end{array}$ & 0 \\
\hline Ringan (kurang sehat) & $\begin{array}{ll}\text { - } & \text { Sebagian kecil daun terserang } \\
\text { - } & \text { Daun rusak antara } 5,1 \%-25 \%\end{array}$ & 1 \\
\hline Agak berat & $\begin{array}{ll}\text { - } & \text { Sebagian besar terdapat lubang } \\
\text { - } & \text { Daun rusak antara } 25,1 \%-50 \%\end{array}$ & 2 \\
\hline Berat & $\begin{array}{l}\text { - } \quad \text { Daun banyak sekali terdapat lubang } \\
\text { - } \quad \text { Daun rusak antara } 50,1 \%-75 \%\end{array}$ & 3 \\
\hline Sangat berat & $\begin{array}{ll}\text { - } & \text { Daun hampir gundul } \\
\text { - } & \text { Daun rusak antara } 75,1 \%-100 \%\end{array}$ & 4 \\
\hline
\end{tabular}

Tabel 1. Klasifikasi derajat kerusakan menurut kriteria Unterstenhofer (1963) dalam Suhaendah (2013)

Table 1. Classification of damage degree according to the criteria of Unterstenhofer (1963) in Suhaendah (2013)

\section{HASIL DAN PEMBAHASAN}

Jenis hama yang menyerang tanaman akor adalah kumbang moncong dengan jenis Hypomeces squamosus, famili curculionidae dan ordo coleoptera. Hama ini telah dilaporkan sebelumnya oleh Thu et al. (2010).
Kumbang moncong dewasa memiliki panjang tubuh kurang lebih $14 \mathrm{~mm}$ dan berbentuk lonjong. Memiliki moncong yang pendek dan antena berbentuk siku. Kumbang moncong dewasa yang baru muncul ditutupi oleh sisik berwarna kuning mengkilap (Gambar 1), lama kelamaan sisik ini menjadi usang. Larva hama ini hidup di dalam tanah dan memakan akar 
tanaman hidup. Memiliki panjang tubuh 15$20 \mathrm{~mm}$ dengan kepala gelap, tubuh meruncing, berwarna putih keabu-abuan dan tanpa kaki (Thu et al., 2010).

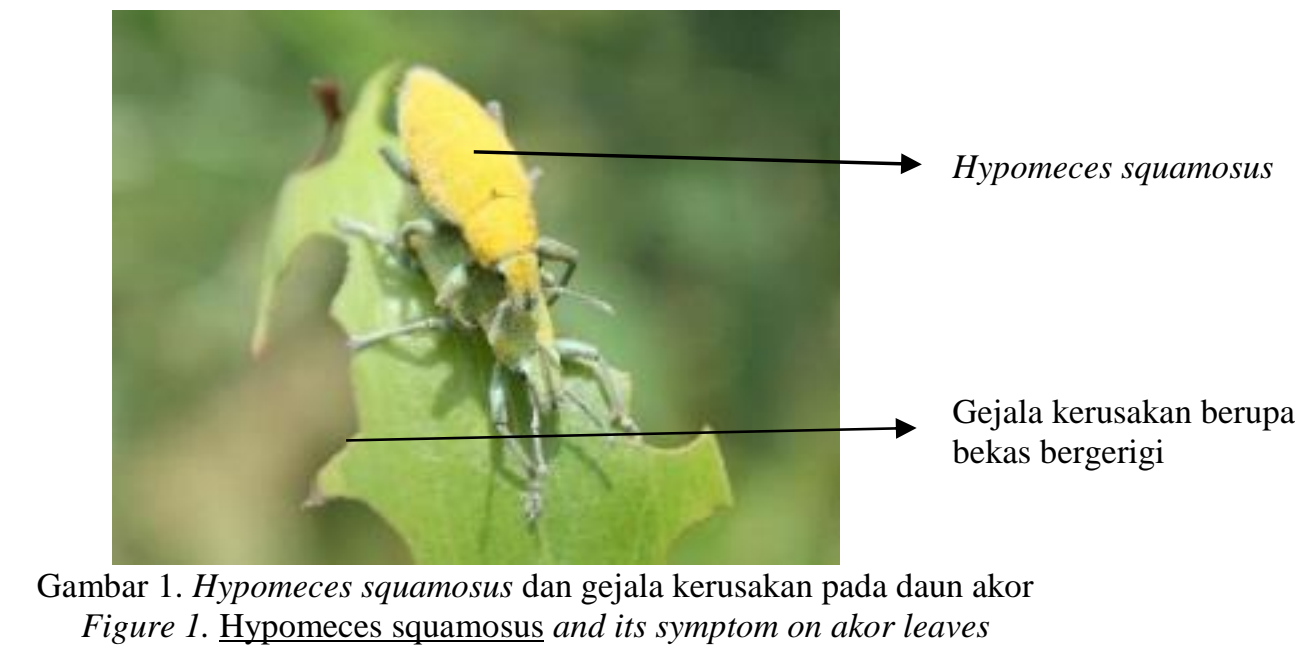

Gejala kerusakan akibat hama ini adalah rusaknya daun akor. Pada daun muda, kumbang moncong dewasa memakan daun dari tepi daun ke dalam sehingga menimbulkan bekas bergerigi (Gambar 1). Pada daun yang lebih tua, kumbang moncong dewasa memakan jaringan yang lebih lunak diantara tulang daun. Akibat dari serangan ini meyebabkan terhambatnya proses fotosintesis karena daun akor yang berkurang. Serangan H. squamosus ditemukan pada tanaman akor yang masih muda (umur 1 tahun). Hasil penelitian Mazumder, Gogoi, Das, and Bora (2015) menunjukkan bahwa $H$. squamosus menyerang tanaman mangga berumur 1-2 tahun. Pada saat populasi sedikit hama ini tidak menimbulkan kerusakan yang berarti. Namun, pada saat populasi hama meningkat, daun-daun akor menjadi rontok sehingga menghambat pertumbuhan akor. Bertambahnya populasi kumbang ini diakibatkan oleh perpindahan $H$. squamosus dari tanaman padi setelah panen ke tanaman akor. Marwoto dan Hardaningsih (2016) menyebutkan bahwa kumbang Hypomeces spp. termasuk tanaman yang tidak penting pada tanaman kedelai. Namun apabila populasi hama cukup tinggi kerusakan yang ditimbulkan cukup berarti.

Kumbang-kumbang dari famili curculionidae dapat ditemukan hampir di mana-mana dan lebih dari 2600 jenis terdapat di Amerika Utara (Borror, Triplehorn, \& F.Johnson, 1996). Kumbang-kumbang moncong menunjukkan variasi yang besar dalam ukuran, bentuk tubuh dan bentuk moncong. Moncong cukup bagus terbentuk pada kebanyakan jenis dengan sungut yang timbul dari kira-kira pertengahan moncong. Semua kumbang moncong kecuali beberapa yang terdapat di dalam sarang-sarang semut adalah pemakan-pemakan tumbuh-tumbuhan dan banyak sebagai hama-hama yang serius. Hampir semua bagian tumbuhan dapat diserang dari akar ke atas. Larva biasanya makan di dalam jaringan-jaringan tumbuhtumbuhan (Borror, Triplehorn, \& Johnson, 1996).

H. squamosus merupakan jenis hama yang polifag yaitu jenis serangga yang memakan lebih dari satu jenis makanan, sehingga memiliki beberapa macam inang yaitu A. auriculiormsi, A. mangium, A.mangium $x$ A. auriculiformis (Acacia hybrid), Eucalyptus spp, jati, pohon buah, padi, jagung, tebu, tembakau, sayuran dan kapas (Thu et al., 2010). Hasil penelitian lainnya menyatakan bahwa $H$. squamosus merupakan kumbang pemakan daun yang menyebabkan kerusakan minor pada tanaman A. auriculiformis, A. mangium dan A. hybrid di Thiland dan Vietnam (Dell, Xu, \& Thu, 
2012). Menurut Boonrahong and Ranamukhaarachchi (2010) H. squamosus menyerang salah satu tanaman ekonomi khas thailand yaitu tangerine. A. Y. C. Chung, Ajik, dan Kimjus (2015) melaporkan bahwa H. squamosus menyerang tanaman Eucalyptus pellita dan E. grandis. Di Malaysia, $H$. squamosus merupakan hama penting pada tanaman hutan kota dengan inang antara lain moluca, akasia, Cinnamomum spp., dan Magnolia champaca. Jenis H.squamosus Fabricius memakan daun
Laran (Neolamarckia cadamba) dengan tingkat kerusakan moderat (A.Y.C. Chung et al., 2009). H. squamosus juga dilaporkan sebagai hama yang menyerang tanaman mangga (Singh, Al-Samararrai, Jaffar, Chemat, \& Islam, 2013). Selain sebagai hama, $H$. squamosus dilaporkan berperan sebagai serangga pollinator di area konservasi tanaman genetik Rambhai Barni Rajabhat University, Thailand (Rassami, Koolkalya, Chaiyakul, \& Sawarit, 2017).

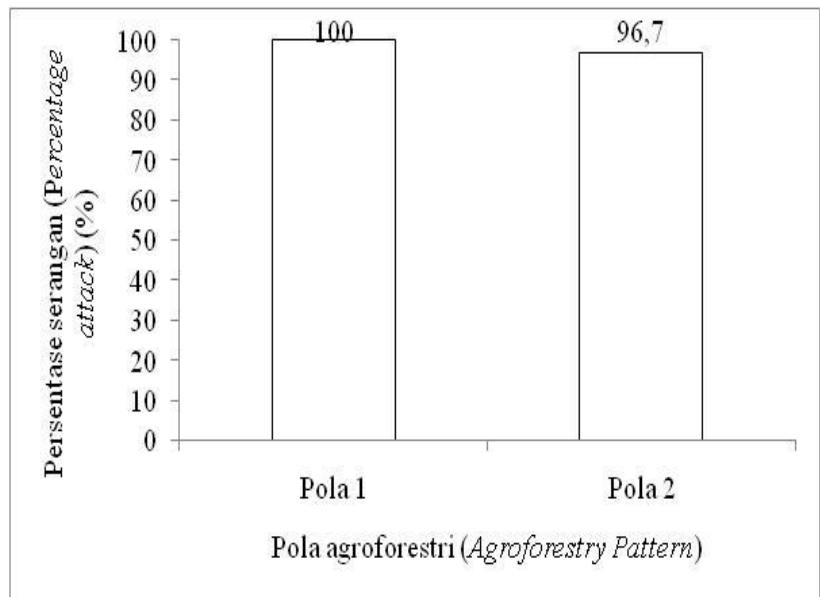

A

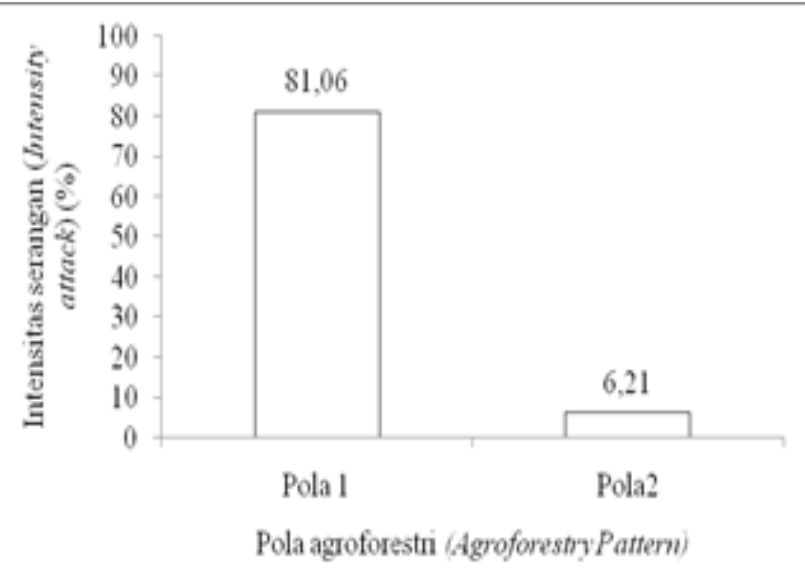

B

Gambar 2. A. Persentase serangan, B. Intensitas serangan H. squamosus pada 2 pola agroforestri Figure 2. A. Percentage attack, B. The intensity of $\mathrm{H}$. squamosus attacks in 2 agroforestry patterns

Hasil pengukuran persentase serangan dan intensitas serangan $H$. squamosus disajikan pada Gambar 2. Persentase serangan H. squamosus mencapai $100 \%$ pada pola 1 dan $96,7 \%$ pada pola 2. Nilai persentase serangan ini tergolong besar. Intensitas serangan $H$. squamosus pada pola 1 termasuk pada kategori sangat berat, artinya daun hampir gundul dan menyebabkan terganggunya pertumbuhan akor sedangkan pada pola 2 intensitas serangannya termasuk kedalam kategori ringan. Intensitas serangan hama pada pola 1 lebih tinggi dibanding pola 2. Tingginya intensitas serangan hama pada pola 1 ini disebabkan adanya tanaman padi. Menurut Thu et al. (2010), padi merupakan inang lain bagi $H$. squamosus. Pada pola 2 tidak terdapat inang lain bagi H.squamosus.
Keberadaan inang lain menciptakan habitat yang sesuai bagi hama untuk tumbuh dan berkembangbiak (Pribadi, 2010).

Ketersediaan makanan yang cukup bagi hama pada pola 1 baik dari padi maupun dari akor menyebabkan populasi hama ini juga tinggi yang mengakibatkan kerusakan pada daun akor. Yasin (2009) menyatakan bahwa makanan yang cukup sangat berpengaruh pada perkembangbiakan hama yaitu dapat meningkatkan populasi hama. Kesesuaian makanan eratkaitannya dengan dinamika serangga memilih sumber makanan yang cocok untuk pertumbuhan populasinya atau dalam proses perkembangbiakan keturunannya. Kualitas makanan suatu bahan mempunyai arti yang sangat dalam kaitannya dengan percepatan perkembangbiakan 
serangga yang pada akhirnya berpengaruh pada tingkatan serangan yang dilakukannya (kualitas dan kuantitas serangan). Selain itu, tingginya intensitas hama kumbang ini juga sesuai dengan pendapat Ratnadass et al. (2012) bahwa adanya satu jenis hama yang dapat menyerang lebih dari satu jenis tanaman dapat menjadikan keragaman jenis tanaman tidak mengurangi serangan hama tersebut.

Upaya pengendalian pada pola 1 perlu dilakukan mengingat intensitas serangannya yang sangat berat. Upaya pengendalian yang dapat dilakukan adalah penerapan Pengendalian Hama Terpadu (PHT). PHT merupakan cara pengendalian hama yang didasarkan pada pertimbangan ekologi dan efisiensi ekonomi dalam rangka pengelolaan ekosistem yang berwawasan lingkungan yang berkelanjutan (Marwoto \& Hardaningsih, 2016). Komponen pengendalian hama yang dapat dipadukan dalam penerapan PHT antara lain pengelolaan ekosistem melalui rotasi tanaman padi dengan jenis lain yang bukan inang $H$. squamosus. Jika terjadi ledakan populasi hama, maka pestisida nabati atau kimiawi secara selektif dapat digunakan untuk mengembalikan populasi hama pada asas keseimbangannya (Marwoto \& Hardaningsih, 2016). Pestisida nabati yang dapat digunakan adalah ekstrak cabai rawit (Singh et al., 2013) yang efektif mengurangi kerusakan akibat $H$. squamosus atau pestisida kimiawi dengan menggunakan insektisida berbahan aktif acephate, carbaryl atau methamidophos yang umum digunakan untuk mengendalikan $H$. squamosusdi hutan kota Malaysia (Lee, 2014).

\section{KESIMPULAN DAN SARAN}

Intensitas serangan kumbang $H$. squamosus pada pola akor+kacang gude hitam+padi dan pola akor+kacang gude hitam+kacang hijau masing-masing sebesar $81,06 \%$ dan $6,21 \%$. Lebih tingginya intensitas serangan $H$. squamosus pada pola akor+kacang gude hitam+padi disebabkan adanya tanaman padi sebagai inang lain $H$. squamosus.

Untuk mengantisipasi kerusakan yang lebih parah, pada pola akor+kacang gude hitam+padi diperlukan upaya pengendalian melalui rotasi dengan jenis tanaman selain inang $H$. squamosus atau dengan aplikasi ekstrak cabai rawit atau insektisida berbahan aktif acephate, carbaryl atau methamidophos.

\section{UCAPAN TERIMA KASIH}

Penulis mengucapkan terima kasih kepada Balai Penelitian dan Pengembangan Teknologi Agroforestry yang telah membiayai penelitian ini, serta kepada Balai Kesatuan Pengelolaan Hutan Produksi Puncak Ngengas-Batulanteh yang telah memfasilitasi lokasi pada penelitian ini, serta kepada petugas dan seluruh tim yang telah membantu proses pengambilan data di lapangan.

\section{DAFTAR PUSTAKA}

Azad, M. S., \& Sumon, M. M. H. (2016). Species specific responses to age on nodule formation, seedling growth, and biomass production of acacia auriculiformis at nursery stage. Journal of Botany, 2016.

Boonrahong, C., \& Ranamukhaarachchi, S. L. (2010). Management of Selected Insect Pests with Pest-Attractive Plants in Organic Tangerine Farming Systems in Northern Thailand. Recent Research in Science and Technology, 2(5), 32-44.

Borror, D. J., Triplehorn, C. A., \& Johnson, N. F. (1996). Pengenalan Pelajaran Serangga (Keenam ed.). Yogyakarta: Gadjah Mada University Press.

Chung, A. Y. C., Ajik, M., \& Kimjus, K. (2015). A Note on Some Pests of Eucalyptus in Sabah, Malaysia. Sandakan, Sabah.

Chung, A. Y. C., Ajik, M., Nilus, R., Hastie, A., Ong, R., \& Chey, V. K. (2009). New Records of Insects Associated with Laran (Neolamarckia cadamba) in Sabah. Sepilok Bulletin, 10, 4564.

Dell, B., Xu, D., \& Thu, P. Q. (2012). Managing Threats to the Health of Tree Plantations in Asia. INTECH. 
Hairiah, K., van Noordwijk, M., \& Suprayogo, D. (2008). Interaksi Antara Pohon-TanahTanaman Semusim: Kunci Keberhasilan Atau Kegagalan Dalam Sistem Agroforestri: Online),(http://www. worldagroforestry. org/sea/Publications/files/lectureno ....

Hendrati, R., Nurrohmah, S., Susilawati, S., \& Budi, S. (2014). Budidaya Acacia auriculiformis untuk Kayu Energi (Cultivation of Acacia auriculiformis for Energy Wood). Bogor: IPB Press.

Hendrati, R. L., Rachmawati, D., \& Pamuji, A. C. (2016). Drought responses on growth, proline content and root anatomy of Acacia auriculiformis Cunn., Tectona grandis L., Alstonia spectabilis Br., and Cedrela odorata L. Jurnal Penelitian Kehutanan Wallacea, 5(2), 123-133.

Lalitha, S. (2015). Ehancement of Acacia auriculiformis Growth using AF Fungi and Cowpea Rizhobium Application. World Journal of Pharmacy and Pharmaceutical Sciences, 4(6), 1269-1266.

Lee, C. Y. (2014). Urban Forest Insect Pests and Their Management in Malaysia. Formosan Entomol., 33, 207-214.

Maharani, J. S., Susilo, F., Swibawa, I. G., \& Prasetyo, J. (2013). Keterjadian Penyakit Tersebab Jamur pada Hama Penggerek Buah Kopi (Pbko) di Pertanaman Kopi Agroforestri. J. Agrotek Tropika, 1(1), 86-91.

Marwoto, \& Hardaningsih, S. (2016). Pengendalian Hama Terpadu pada Tanaman Kedelai.

Mazumder, N., Gogoi, S., Das, P., \& Bora, P. (2015). A new record of mango weevil, Hypomeces squamosusus (F)(Coleoptera: Curculionidae) on young mango plant from Assam. Biotic Environment, Formerly Insect Environment $21(2 \& 3)$.

Pribadi, A. (2010). Serangan Hama dan Tingkat Kerusakan Daun Akibat Hama Defoliator pada Tegakan Jabon ( Anthocephalus cadamba Miq.). Jurnal Penelitian Hutan dan Konservasi Alam, VII(4), 451-458.

Pumarino, L., Sileshi, G. W., Gripenberg, S., Kaartinen, R., Barrios, E., Muchane, M. N., . . . Jonsson, M. (2015). Effects of agroforestry on pest, disease and weed control: A metaanalysis.

Rassami, W., Koolkalya, S., Chaiyakul, K., \& Sawarit, S. (2017). Species Diversity of Insect Pollinators in the Area of Plant Genetics Conservation Project under the Royal
Initiation of Her Royal Highness Princess Maha Chakri Sirindhorn (RSPG) at the Rambhai Barni Rajabhat University, Chanthaburi Province, Thailand. International Journal of Agricultural Technology, 13(7.1), 1259-1267.

Ratnadass, A. J., Fernandes, P., Avelino, J., \& Habid, R. (2012). Plant Species Diversity for Sustainable Management of Crop Pests and Diseases an Agroecosystems: a Review. Agronomy, Sustainability and Development, 32, 273-303. doi:DOI 10.1007/s13593-011$0022-4$

Schroth, G., Krauss, U., Gasparotto, L., Aguilar, J. D., \& Vohland, K. (2000). Pests and diseases in agroforestry systems of the humid tropics. Agroforestry Systems, 50(3), 199-241.

Singh, H., Al-Samararrai, G. F., Jaffar, M. H., Chemat, M. H., \& Islam, A. K. M. S. (2013). Performance of Five Plant Extract On-LeafCuttingbeetle Hypomeces squamosus on Harumanis Variety of Mango in Perlis, Malaysia. International Journal of Agricultural Science and Research (IJASR), 3(1), 89-98.

Sudiono, Sutjahyo, S. H., Wijayanto, N., Hidayat, P., \& Kurniawan, R. (2017). Vegetation Diversity And Intensity Of Plant Pests And Diseases In Two Polyculture Systems In Tanggamus District. Jurnal Hama dan Penyakit Tumbuhan Tropika, 17(2), 137-146.

Suhaendah, E. (2013). Hama Kumbang Sastra sp pada Agroforestry Manglid. Paper presented at the Seminar Nasional Agroforestri 2013, Malang.

Thu, P. Q., Griffiths, M. W., Pegg, G. S., McDonald, J. M., Wylie, F. R., King, J., \& Lawson, S. (2010). Healthy Plantations. A fiel guide to pests and pathogens of Acacia, Eucalyptus and Pinus in Vietnam. Retrieved from Queensland, Australia:

Utami, S., \& Ismanto, A. (2017). Serangan Hama Defoliator pada Pola Tanam Monokultur dan Agroforestri Jabon. Jurnal Sains Natural, 5(1), 42-48.

Yasin, M. (2009). Kemampuan Akses Makan fFaktor Fisikokimia yang Mempengaruhinya. Paper presented at the Seminar Nasional Serealia. 